\title{
Peran Syukur sebagai Moderator Pengaruh Perbandingan Sosial terhadap Self-esteem pada Remaja Pengguna Media Sosial
}

\author{
Johan Satria Putra \\ Fakultas Psikologi Universitas YARSI, Jakarta - Indonesia
}

\begin{abstract}
Adolescents consistently compare themselves with others they see on social media. This habit can bring up in them a sense of envy or inferiority, which then can lead to a decrease in self-esteem. Therefore, it is necessary to have aspects that can increase their confidence and optimism, including in term of spirituality, their sense of gratitude. The purpose of this study was to see the role of gratitude as moderating variable in the influence of social comparison on the self-esteem of social media adolescent users. The research was conducted using social comparison scale of Iowa-Netherlands Comparison Orientation Scale (INCOM), gratitude scale, and selfesteem state scale, which were distributed to 200 social media adolescent users in DKI Jakarta, were involved through incidental sampling. The results of data analysis showed that there was a significant role of gratitude in influencing social comparison to change these participants' self-esteem. The sense of gratitude served to increase these adolescents' self-esteem, which previously decreased as a result of social comparison. This study had a number of weaknesses in the use of the instruments, especially the social comparison scale. Any similar study in the future is expected to focus more on one kind of social media.
\end{abstract}

Keywords: adolescent; self-esteem; social comparison; social media

\begin{abstract}
Abstrak: Remaja seringkali membandingkan diri dengan orang lain yang dilihatnya ketika mengakses media sosial, yang kemudian dapat menimbulkan rasa iri atau yang mengarah kepada penurunan self-esteem (rendah diri/minder). Dengan demikian diperlukan adanya aspek yang dapat meningkatkan kepercayaan diri dan rasa optimisnya, termasuk dari segi spiritualitas, seperti salah satunya adalah kebersyukuran. Tujuan penelitian ini adalah untuk melihat peran dari syukur sebagai variabel moderator, dalam pengaruh perbandingan sosial terhadap self-esteem remaja pengguna media sosial. Penelitian dilakukan dengan instrumen skala perbandingan sosial Iowa-Netherlands Comparison Orientation Scale (INCOM), skala syukur, dan self-esteem state scale yang dibagikan kepada 200 orang remaja pengguna media sosial di DKI Jakarta dengan menggunakan incidental sampling. Hasil analisis data dengan menggunakan moderated regression analysis menunjukkan bahwa terdapat peran yang signifikan dari syukur dalam pengaruh perbandingan sosial terhadap self-esteem remaja pengguna media sosial. Syukur berfungsi meningkatkan self-esteem dari remaja yang bersangkutan yang menurun sebagai dampak dari perbandingan sosial.
\end{abstract}

Kata Kunci: media sosial; perbandingan sosial; remaja; self-esteem

Corresponding Author: Johan Satria Putra (e-mail: johan.satria@yarsi.ac.id), Program Studi Psikologi, Fakultas Psikologi Universitas YARSI (Yayasan Rumah Sakit Islam Indonesia) Jl. Letjend Suprapto, Cempaka Putih, Jakarta Pusat 10510. 


\section{Pendahuluan}

Perkembangan teknologi meliputi juga perkembangan teknologi informasi. Di antara perkembangan teknologi informasi tersebut yang paling nampak di dalam keseharian hidup manusia adalah berubahnya alat telekomunikasi. Proses perubahan alat komunikasi manusia ini berlangsung semakin cepat, bahkan kadang tidak terasa. Beberapa tahun yang lalu, telepon masih sangat membantu manusia untuk melakukan percakapan jarak jauh. Kehadiran pager yang kemudian disusul dengan handphone, memulai era telekomunikasi nirkabel.

Terkoneksinya handphone dengan internet, atau dapat disebut juga smartphone, memungkinkan tersedianya media sebagai wadah berkomunikasi antar manusia melalui sambungan internet tersebut. Media ini biasa disebut dengan istilah media sosial. Perkembangan media sosial sendiri dimulai sekitar tahun 1997 yang ditandai dengan kemunculan situs media sosial pertama di dunia, Sixdegree.com. Kemudian pada tahun 2002, muncul friendster yang lantas menjadi media sosial yang fenomenal pada masa tersebut. Setelah itu orang-orang mulai beralih ke facebook, twitter, dan begitu seterusnya media sosial terus bertambah macamnya (Roesma \& Mulya, 2018).

Media sosial internet kini telah menjelma sebagai sebuah media komunikasi primer bagi manusia, tak terkecuali di Indonesia. Bahkan dapat dilihat dalam berbagai aktivitas manusia justru lebih banyak berinteraksi dengan situs media sosialnya, dibandingkan dengan berinteraksi secara interpersonal dengan orang yang ada di sekitarnya. Akses informasi yang luas dan cepat di media sosial memungkinkan seseorang yang menggunakannya lebih mudah untuk mengetahui dan mengeksplorasi segala bentuk kegiatan atau kondisi yang ada kepada orangorang lain yang berada pada jarak jauh. Tidak terkecuali dengan informasi-informasi terkait apa yang sedang dilakukan ataupun situasi yang sedang dialami oleh teman online ini. Misalnya seperti lokasi di mana keluarga atau teman berada, aktivitas apa yang sedang mereka lakukan, bahkan perasaan emosi yang sedang mereka rasakan. Dalam dunia maya, hal ini biasa disebut dengan istilah stalking (Roesma \& Mulya, 2018).

Di antara media sosial terkini yang memfasilitasi penggunanya untuk dapat saling mengetahui kegiatan orang lain adalah facebook, twitter, path, dan instagram. Berdasarkan survei Asosiasi Penyelenggara Jasa Internet Indonesia (APJII), jumlah pengguna internet di Indonesia tahun 2016 bisa mencapai 132,7 juta orang, dengan 98,3 \% di antaranya menggunakan telepon genggam sebagai sarana mengakses (Widiartanto, 2016). Facebook masih menjadi media sosial dengan jumlah pengguna terbanyak, yaitu sekitar 71,6 juta orang. Namun, media sosial lain juga makin berlipat jumlah pemakainya, dan mulai menyaingi facebook. Salah satu media sosial sedang populer dewasa ini adalah instagram, yang jumlah penggunanya di Indonesia mencapai 19,9 juta (Hidayat, 2016).

Pada dasarnya, media sosial memiliki banyak kelebihan, di antaranya sebagaimana yang disebutkan di atas, yaitu mempermudah akses informasi serta komunikasi dengan orang-orang lain tanpa batasan ruang dan waktu. Fungsi utama dari media sosial adalah untuk terhubung dan berkomunikasi dengan orang-orang yang berada di tempat lain, berkenalan, sekaligus untuk memuaskan rasa ingin tahu individu mengenai informasi-informasi terkait temannya di dunia maya. Bentuk-bentuk informasi yang tersedia di dalam media sosial, atau biasa disebut sebagai profiles meliputi berbagai konten, antara lain seperti identitas personal, foto-foto, status, yang kesemuanya merupakan sebuah representtasi diri (self-presentation). Self presentation ter- 
sebut dapat berbentuk visual maupun tulisan (Herring \& Kapidzic, 2015).

Ekspos seseorang terhadap self presentation dari teman online seringkali dapat menimbulkan dampak psikologis tertentu pada individu bersangkutan, termasuk pada self-esteem yang dimiliki. Misalnya temuan penelitian Gonzales dan Hancock (2011) bahwa intensitas yang tinggi dalam melihat profil facebook orang lain dibandingkan melihat profil facebook sendiri, dapat berdampak kepada penurunan self-esteem. Sementara hasil penelitian lain menemukan bahwa self-esteem secara sosial dapat meningkatkan pengaruh media terhadap body image remaja (Fernandez \& Pritchard, 2012).

Pada dasarnya berbagai pengaruh tersebut juga turut ditentukan oleh adanya perbandingan sosial yang dilakukan oleh pengguna media sosial yang bersangkutan. Ekspos terhadap profil teman online akan lebih berpengaruh terhadap self-esteem, ketika individu yang bersangkutan memiliki perilaku perbandingan sosial yang tinggi (Fardouly, Diedrichs, Vartanian, \& Halliwell, 2015). Hasil penelitian Krasnova, Wenninger, Widjaja, \& Buxmann (2013) menunjukkan bahwa melihat secara eksplisit dan implisit orang lain yang lebih kaya, sukses, dan bahagia di media sosial dapat mendorong perilaku perbandingan sosial dan menyebabkan perasaan rendah diri.

Memperbandingkan diri dengan orang lain dapat disebut dengan istilah perbandingan sosial. Teori Perbandingan Sosial (Festinger, dalam Baumeister \& Finkel, 2010) menyatakan bahwa seorang individu senantiasa memiliki dorongan untuk mengevaluasi dirinya. Di dalam proses evaluasi tersebut, individu umumnya menggunakan suatu objek ataupun bukti tertentu yang dapat dijadikan sebagai bahan perbandingan. Bukti perbandingan sosial ini dapat diambil dari orang-orang yang dianggap mirip dengan individu yang bersangkutan, atau dengan kata lain dijadikan sebagai referensi baginya.

Perbandingan sosial yang dilakukan oleh individu umumnya ditujukan untuk mengevaluasi bagaimana kemampuan (abilities) dan pendapat (opinion) yang dimilikinya ketika dibandingkan dengan kemampuan dan opini dari orang lain yang menjadi pembanding. Temuan lain menunjukkan bahwa ketika seseorang tidak memiliki pendapat yang kuat akan sesuatu pada dirinya sendiri, maka dia akan terdorong untuk membandingkannya dengan orang lain. Dalam hal ini, media sosial seringkali menjadi ranah bagi individu untuk mencari perbandingan bagi dirinya dalam hal kemampuan dan opini tersebut (Lee, 2014).

Perbandingan sosial terdiri dari dua macam, yaitu perbandingan sosial ke bawah (downward social comparison) dan perbandingan sosial ke atas (upward social comparison). Perbandingan sosial ke bawah adalah membandingkan diri dengan orang lain yang dianggap lebih buruk dalam beberapa atribut tertentu yang dimiliki. Pada umumnya individu melakukan downward comparison ini bertujuan untuk menciptakan perasaan positif dan meningkatkan self-esteem. Sementara itu, perbandingan sosial ke atas merupakan perilaku membandingkan diri dengan orang lain yang dianggap lebih baik dalam hal tertentu. Efek dari perbandingan sosial ini, baik upward maupun downward, terkadang tidak berlaku apabila orang yang menjadi bahan pembanding memiliki hubungan yang dekat (Baron \& Byrne, 2004).

Menjadikan orang lain sebagai bahan referensi perbandingan dimaksudkan untuk membuat ukuran yang seakurat mungkin mengenai kemampuan dirinya sendiri, maupun juga untuk melihat apakah sikap dan perilaku yang dia 
lakukan benar atau tidak. Terdapat beberapa tujuan dari dilakukannya perbandingan sosial oleh seseorang (Taylor, 1998). Pertama, adalah untuk melakukan evaluasi diri secara akurat. Kedua, sebagai self-enhancement atau peningkatan diri. Apabila seseorang merasa self-esteem-nya terancam, biasanya dia akan membandingkan diri dengan orang lain yang dianggap lebih buruk, sehingga menjadikannya lebih tenang. Ketiga, terkadang individu juga membutuhkan perbandingan sosial ke atas (upward compareison) untuk memotivasi dirinya menjadi lebih baik (self-improvement). Keempat, adalah untuk memperoleh konformitas kelompok.

Di sisi lain, membandingkan diri dengan orang lain di media sosial juga memiliki kecenderungan untuk menimbulkan kecemburuan sosial. Kecemburuan ini selanjutnya dapat menyebabkan emosi negatif pada diri orang-orang yang, entah secara sadar ataupun tidak sadar, menimbulkan perasaan minder atau rendah diri. Perasaan rendah diri berhubungan erat dengan self-esteem. Sejumlah penelitian terdahulu menunjukkan bahwa rasa iri yang diperoleh dari mengekspos media sosial milik orang lain dapat mengakibatkan penurunan self-esteem (Fardouly et al., 2015; Gonzales \& Hancock, 2011).

Self-esteem merupakan sumber evaluasi bagi diri dan sikap seseorang, sekaligus judgment bagi konsep diri dalam hal afeksi. Self-esteem meliputi perasaan bernilai dan menerima diri, yang sifatnya berkembang dan menetap, sebagai konsekuensi dari kesadaran akan kompetensi diri yang ditambah dengan umpan balik dari luar (Damian \& Robins, 2010). Dengan kata lain, self-esteem merupakan suatu bentuk evaluasi terhadap konsep diri, yang meliputi kompetensi dan pencapaian sebagai elemennya. Self-esteem bersifat fluktuatif dan bervariasi tergantung pada pengalaman yang dirasakan individu.
Seorang yang memiliki self-esteem yang tinggi mengartikan bahwa orang tersebut menyukai dirinya sendiri, begitupun sebaliknya. Self-esteem seringkali diukur dengan membandingkan antara ideal self seseorang dengan realita dirinya yang sebenarnya, kemudian melihat perbedaan di antara keduanya (Baron \& Byrne, 2004). Self-esteem memiliki tiga konstruk yang berbeda berdasarkan sudut pandangnya, yaitu global self-esteem, feeling of self-worth (perasaan bernilai), serta self-evaluation (evaluasi diri). Ketiga bentuk konstruk self-esteem ini sendiri dapat dilihat dalam tiga model, yaitu cognitive (bottom-up) model, affective (top-down) model, dan dengan menggabungkan keduanya (Brown \& Marshall, dalam Kernis, 2013).

Di dalam diri remaja, self-esteem berhubungan dengan kepercayaan diri. Domain kompetensi remaja meliputi kompetensi pekerjaan, ketertarikan romantik, dan hubungan yang dekat. Dalam hal ini, teman sebaya atau peer group memiliki pengaruh yang kuat terhadap tingkat rasa percaya diri remaja. Pada sebagian besar remaja, rendahnya self-esteem dan kepercayaan diri ini dapat menyebabkan masalah penyimpangan perilaku, seperti: depresi, anoraksia (gangguan pola makan), delikuensi (nakal), serta berbagai masalah penyesuaian diri (Santrock, 2003).

Rendahnya self-esteem sendiri dapat menyebabkan timbulnya efek-efek negatif lain dalam diri individu. Seperti misalnya masalah kesehatan mental, perilaku delikeunsi, serta sikap yang negatif terhadap masa depan (Trzesniewski et al., 2006). Pada diri remaja, umumnya permasalahan self-esteem ini menyangkut body image atau gambaran mengenai tubuh. Tidak jarang juga berpengaruh terhadap keyakinan diri akan masa depan hubungan dengan pasangan close relationship (Srivastava, McGonigal, Richards, Butler, \& Gross, 2006). 
Pada dasarnya, masa remaja memang merupakan masa di mana seseorang akan sering membandingkan dirinya dengan teman-teman di sekitarnya. Sebagaimana disebutkan di atas, dengan memperbandingkan diri dapat menyebabkan seorang remaja menjadi kurang percaya diri. Namun, agama (dalam hal ini Islam) menekankan bahwa sebaiknya seorang manusia tidak selalu melihat ke atas dalam hal duniawi, karena dapat menyebabkan perasaan kufur nikmat (Al-Banjari, 2014).

Masa remaja juga merupakan masa di mana seseorang masih mencari jati diri, dan masih berada dalam tahap awal dalam memperdalam suatu ilmu, termasuk agama. Pada masa seperti ini, remaja pada umumnya memiliki pengalaman dan penghayatan yang masih sangat minim dalam hal agama, termasuk untuk dapat mensyukuri segala nikmat Allah (Jalaluddin, 2009).

Bersyukur sejatinya juga lebih mendatangkan manfaat bagi remaja itu sendiri. Seperti misalnya studi yang dilakukan oleh Giacomo Bono (dalam Beritasatu, 2012) yang menemukan bahwa remaja yang selalu mengucap syukur dalam hidupnya, akan memiliki beberapa keunggulan, seperti lebih mudah diajak bekerja sama, kreatif, memiliki tujuan hidup, dan daya tahan tinggi. Begitu pula ketika remaja yang sering di-bully di media sosial, seperti mereka yang jomblo missalnya, akan lebih dapat menyikapi secara positif kondisi yang mereka hadapi.

Sebagai sebuah komponen psikologis, gratitude atau kebersyukuran merupakan perwujudan dari rasa kagum, perasaan berterima kasih, dan penghargaan atas hidup yang dijalani. Perasaan kagum, terima kasih, dan penghargaan tersebut dapat ditujukan kepada pihak lain, baik itu kepada sesama manusia maupun yang bukan manusia seperti Tuhan atau makhluk hidup lain (Emmons \& Shelton dalam Lopez \& Snyder,
2012). Terdapat banyak definisi dari gratitude atau kebersyukuran dalam ilmu psikologi. Gratitude sering diartikan sebagai respons positif ketika menerima sesuatu yang dianggap menguntungkan. Dapat juga berarti nilai tambah yang berkaitan dengan penilaian bahwa ada pihak lain yang bertanggung jawab akan nilai tambah tersebut (Emmons \& McCullough, 2012). Terdapat tiga komponen kebersyukuran, yaitu: penghargaan yang hangat terhadap seseorang atau sesuatu; niat baik terhadap orang atau sesuatu; dan perilaku yang merupakan implikasi dari penghargaan dan niat baik orang atau sesuatu tersebut (Fitzgerald, dalam Emmons \& McCullough, 2012).

Rasa bersyukur dapat menumbuhkan suatu kondisi penerimaan diri individu, atau self acceptance. Self acceptance merupakan salah satu bagian dari psychological well-being dan turut menentukan tinggi-rendahnya self-esteem seseorang. Seseorang yang mampu menerima dirinya akan memandang dirinya sebagai orang yang berharga dan menerima kelebihan dan kekurangan yang dimiliki (Utami, 2013). Hasil penelitian Kashdan, Uswatte, dan Julian (2006) menunjukkan bahwa gratitude atau bersyukur dapat memunculkan self-esteem dan emosi positif di dalam kehidupan sehari-hari. Dalam hal ini, bersyukur menjadi salah satu metode coping yang dilakukan seseorang, khususnya remaja, untuk mengatasi rendahnya kepercayaan diri (Santrock, 2003). Hal ini juga terkait rasa syukur sebagai faktor pembentuk kebahagiaan (happiness).

Syukur juga mengarahkan individu untuk lebih melihat ke bawah dalam hal-hal yang bersifat duniawi, atau dengan kata lain melihat fakta bahwa masih banyak orang yang lebih tidak beruntung daripada dirinya (Al-Banjari, 2014). Sementara orang yang melakukan downward comparison cenderung akan lebih mengevaluasi 
positif dirinya dan menerima kondisi dirinya (Vogel, Rose, Roberts, \& Eckles, 2014). Hal ini menunjukkan bahwa secara tidak langsung, kebersyukuran dapat meningkatkan self-esteem seseorang melalui mekanisme perbandingan sosial ke bawah.

Mengekspos atau melihat apa yang dipresentasikan oleh orang lain di media sosial dapat memengaruhi tingkat self-esteem seorang remaja. Mekanisme ini didukung oleh pembentukan identitas diri pada remaja, yang pada umumnya menjadikan peer group-nya sebagai referensi dalam evaluasi diri dalam hal kemampuan (ability) dan pendapat (opinion), atau dengan kata lain sebagai objek perbandingan sosial (Lee, 2014). Oleh karena itu, ketika seorang remaja membandingkan dirinya dengan peer groupnya atau orang lain yang dianggap lebih baik dari dirinya dalam kemampuan melakukan sesuatu, ataupun ketika remaja merasa bahwa pendapatnya tidak sama atau tidak diterima oleh peer groupnya, maka hal ini dapat menurunkan selfesteem remaja yang bersangkutan. Beberapa hasil penelitian terdahulu juga menunjukkan bahwa perbandingan sosial melalui media sosial dapat memengaruhi self-esteem seseorang secara negatif (Gonzales \& Hancock, 2011; Krasnova et al., 2013; Vogel et al., 2014) .

Di sisi lain, rasa syukur dapat meningkatkan well-being dan emosi positif seseorang, serta dapat mendorongnya untuk lebih menerima kondisi dirinya. Selain itu, syukur juga mengarahkan seseorang untuk lebih melakukan downward comparison atau perbandingan sosial ke bawah, sehingga dapat meningkatkan kepercayaan diri dan menerima kondisi dirinya. Oleh karena itu, syukur berpengaruh secara tidak langsung terhadap peningkatan self-esteem (Emmons \& McCullough, 2012). Berbagai dinamika ini menunjukkan bahwa syukur memiliki peran untuk mengurangi pengaruh negatif perbandingan sosial terhadap self-esteem seorang remaja.
Sejumlah penelitian terdahulu menunjukkan perbandingan sosial dapat berimplikasi negatif bagi self-esteem seseorang, khususnya remaja. Sehingga dibutuhkan adanya variabel yang mampu mengurangi pengaruh negatif dari perbandingan sosial tersebut. Dalam Islam, salah satu variabel yang berpengaruh adalah kebersyukuran. Melalui rasa syukur, remaja dapat lebih bisa meningkatkan penerimaan diri dan optimismenya yang menurun akibat perbandingan sosial, sehingga dapat menghasilkan selfesteem yang lebih positif. Akan tetapi, belum banyak penelitian di Indonesia yang mengungkap pengaruh syukur menurut Islam, dalam kaitannya dengan perbandingan sosial di media sosial dan juga self-esteem. Dinamika ini menjadikan peneliti tertarik untuk melihat lebih jauh, apakah rasa syukur dapat mengurangi pengaruh negatif dari perbandingan sosial terhadap selfesteem remaja yang menjadi pengguna media sosial. Diharapkan dari hasil penelitian ini nantinya dapat dijadikan sebagai pedoman dalam mengelola konten media sosial yang lebih dapat mengakomodir afeksi penggunanya.

Hipotesis yang hendak diuji dalam penelitian ini, yaitu Ha : terdapat peran syukur dalam pengaruh perbandingan sosial terhadap self-esteem pengguna media sosial.

\section{Metode}

Populasi subjek dalam penelitian ini adalah pelajar dan mahasiswa di DKI Jakarta. Sampel diambil dengan menggunakan teknik incidental sampling (Hadi, 2015). Dalam pemilihan subjek ini, kriteria yang diambil adalah remaja dengan kisaran usia 14-19 tahun. Pertimbangannya, remaja berada pada masa mereka banyak mengambil peer group sebagai acuan konformitas, evaluasi diri, dan perbandingan sosial (Santrock, 2003). 
Kriteria selanjutnya, subjek adalah pengguna aktif dari minimal salah satu media sosial yaitu facebook atau instagram. Dua jenis media sosial ini dipilih karena merupakan media sosial yang memiliki persentase jumlah pengguna remaja yang tinggi (Hidayat, 2016). Di samping itu, kedua media sosial tersebut juga menyediakan banyak fitur foto-foto personal dan juga status terkini, yang cenderung mudah memprovokasi perilaku perbandingan sosial (Krasnova et al., 2013; Vogel et al., 2014)

Penelitian ini menggunakan pendekatan kuantitatif, yang menggunakan skala dan angket sebagai alat pengumpul data. Terdapat empat macam skala dan angket yang dipergunakan dalam penelitian ini, yaitu: skala orientasi perbandingan sosial, skala arah perbandingan sosial, Skala Self-esteem, serta Skala Syukur.

Skala orientasi perbandingan sosial menggunakan Iowa-Netherlands Comparison Orientation Scale (INCOM) yang telah diadaptasi ke dalam bahasa Indonesia dan disesuaikan dengan konteks penelitian (Schneider \& Schupp, 2014). Skala INCOM ini merupakan skala multidimensi yang terbagi menjadi dua dimensi dari perbandingan sosial, yaitu abilites dan opinion. Skala self-esteem mengadaptasi State Self-esteem Scale (Heatherton \& Polivy, 1991) yang juga telah dimodifikasi dan disesuaikan dengan konteks penelitian. Sedangkan skala syukur diambil dari hasil penelitian terdahulu peneliti (Putra, 2016), yang beberapa itemnya disesuaikan ulang dengan konteks penelitian.

Pengujian alat ukur dilakukan dengan menggunakan uji reliabilitas dan validitas isi. Validitas isi dijaga dengan melakukan proses seleksi item. Seleksi item ditentukan dengan melihat nilai korelasi item-total, di mana item yang memiliki nilai koefisien $<0,300$ dianggap memiliki daya beda yang kurang baik dan tidak akan disertakan dalam proses pengambilan data. Uji coba alat ukur dilakukan dengan membagikan skala INCOM, Skala Syukur, dan State self-esteem State kepada 99 orang mahasiswa. Proses uji reliabilitas dan seleksi item dilakukan dengan menggunakan software SPSS 20.0.

Berdasarkan hasil pengujian alat ukur, maka dapat disimpulkan bahwa ketiga alat ukur yang digunakan dapat dikatakan sebagai alat ukur yang reliabel $(\mathrm{r}>.700)$, dengan nilai koefisien Alpha Cronbach masing-masing adalah 0,739 untuk skala perbandingan sosial, 0,826 untuk skala syukur, dan 0,861 untuk skala self-esteem. Sedangkan berdasarkan hasil seleksi item, maka jumlah item untuk masing-masing skala yang akan dipergunakan dalam penelitian adalah sebanyak 9 item untuk skala INCOM, 18 untuk skala syukur, dan 19 item untuk state self-esteem scale.

Analisis data dilakukan dengan menggunakan metode uji korelasi untuk menguji hipotesis. Uji korelasi dilakukan dengan menggunakan teknik moderated regression analysis (MRA), untuk melihat pengaruh perbandingan sosial terhadap self-esteem, dengan syukur sebagai variabel moderator. Dikarenakan skala perbandingan sosial yang dipergunakan bersifat multidimensi, maka diterapkan juga uji regresi sederhana untuk masing-masing dimensi, yaitu dimensi abilities terhadap self-esteem dan dimensi opinion terhadap self-esteem. Seluruh prosedur analisis data dilakukan dengan bantuan software SPSS 21.0 (Hartono, 2013).

\section{Hasil}

Subjek dalam penelitian ini berjumlah 200 orang remaja pengguna media sosial di DKI Jakarta. Pengumpulan data dilakukan dengan menyebar angket atau skala kepada subjek, baik secara langsung maupun melalui online. Jumlah subjek laki-laki sebanyak 89 orang dan perempuan 111 orang. Usia subjek berkisar antara 
16 hingga 19 tahun, dengan jumlah terbanyak adalah subjek dengan usia 17 tahun yaitu sebanyak 124 orang atau $62 \%$. Sementara dari segi pendidikan yang tengah ditempuh, sebagian besar subjek masih bersekolah di SMA, yaitu sebanyak 177 orang atau 88,5\%. Berdasarkan lamanya mengakses media sosial setiap harinya, sebanyak 89 subjek mengakses selama 2 hingga 5 jam per hari, 62 orang mengakses 5-8 jam per hari, dan 49 orang menggunakan media sosial selama lebih dari 8 jam per hari. Media sosial yang paling banyak digunakan oleh subjek adalah instagram, di mana semua subjek dalam penelitian ini memiliki akun instagram dan 108 orang di antaranya mengaku paling sering mengakses instagram dibandingkan media sosial lain.

Sebelum melakukan uji hipotesis, perlu dilakukan terlebih dahulu uji asumsi, yang terdiri dari uji normalitas, linieritas, dan uji korelasi. Uji normalitas dilakukan untuk melihat apakah pesebaran data terdistribusi normal atau tidak. Uji normalitas yang digunakan adalah ShapiroWilk, dengan kriteria data yang dianggap normal apabila nilai signifikansi yang diperoleh berada di atas 0,05. Hasil uji normalitas menunjukkan sebaran data perbandingan sosial tidak normal, baik untuk dimensi abilities maupun opinion, dengan $\mathrm{p}=0,000 \quad(\mathrm{p}<0,01)$. Sedangkan data variabel self-esteem terdistribusi normal dengan $\mathrm{p}=0,143 \quad(\mathrm{p}>0,05)$. Dikarenakan data variabel terikat masih terdistribusi normal, maka uji hipotesis dapat dilakukan dengan teknik statistik parametrik.

Uji linieritas dilakukan untuk melihat ada tidaknya hubungan yang linier antara variabel bebas dengan variabel terikat. Apabila nilai signifikansi berada di bawah 0,05 , maka dapat dikatakan bahwa terdapat hubungan linier antara kedua variabel tersebut. Berdasarkan hasil uji linieritas yang dilakukan, maka dapat disimpulkan bahwa terdapat hubungan yang linier antara perbandingan sosial dengan selfesteem $(\mathrm{p}=0,000 ; \mathrm{p}<0,01)$.

Uji asumsi selanjutnya yang perlu untuk dilakukan sebelum melakukan uji regresi adalah uji korelasi. Uji korelasi dilakukan antara variabel perbandingan sosial dengan self-esteem. Hasilnya ditemukan bahwa terdapat hubungan yang sangat signifikan antara dimensi abilities perbandingan sosial dengan self-esteem pada subjek $(\mathrm{p}=0,000 ; \mathrm{p}<0,01)$. Begitu juga antara dimensi opinion dengan self-esteem, terdapat hubungan yang signifikan ( $p=0,001 ; p<0,01)$. Dengan demikian, maka prosedur uji hipotesis dengan menggunakan uji regresi dapat dilakukan.

Berdasarkan hasil moderated regression analysis (MRA), ditemukan bahwa terdapat peran yang signifikan dari variabel perbandingan sosial terhadap self-esteem setelah dimoderasi oleh variabel syukur $(\mathrm{p}=0,000 ; \mathrm{p}<0,01)$. Dengan demikian, maka dapat disimpulkan bahwa Ha diterima, yang artinya terdapat peran syukur dalam pengaruh perbandingan sosial terhadap self-esteem remaja pengguna media sosial.

Analisis regresi sederhana diterapkan untuk melihat peran dari masing-masing dimensi perbandingan sosial. Hasilnya ditemukan terdapat pengaruh negatif yang signifikan dari dimensi abilities perbandingan sosial terhadap self-esteem remaja pengguna media sosial $(\mathrm{p}=0,000 ; \mathrm{p}<0,01)$, dengan koefisien korelasi $r=-0,264$. Setelah dimoderasi oleh syukur, signifikansi pengaruh dimensi abilities perbandingan sosial tersebut tidak berubah, namun koefisien korelasi berubah menjadi $r=-0,255$. Perubahan ini bermakna bahwa variabel syukur menurunkan pengaruh negatif dari dimensi abilities perbandingan sosial terhadap self-esteem. Sementara hasil regresi sederhana untuk melihat peran dari dimensi opinion perbandingan sosial terhadap self-esteem remaja pengguna media sosial juga menunjukkan pe- 
ngaruh negatif yang signifikan ( $\mathrm{p}=0,001 ; \mathrm{p}<0,01)$, dengan koefisien korelasi $r=-0,240$. Sama seperti pada dimensi abilities, setelah dimoderasi oleh syukur signifikansi pengaruh dimensi opinion perbandingan sosial tersebut tidak berubah, dan koefisien korelasi berubah menjadi r=-0,198.

Sementara itu ditemukan perubahan koefisien determinasi dari 0,092 menjadi 0,227 pada peran perbandingan sosial terhadap selfesteem. Artinya, terdapat peningkatan kontribusi dari perbandingan sosial terhadap self-esteem pada remaja pengguna media sosial setelah dimoderasi oleh syukur sebesar 13,5\%. Dinamika ini juga dapat dilihat dari persamaan regresi $Y=$ 43,020 - 0,260 X1 - 0,398 X2 + 0,344 X3, dengan $\mathrm{Y}$ adalah self-esteem, X1 merupakan dimensi abilities perbandingan sosial, $\mathrm{X} 2$ dimensi opinion perbandingan sosial, dan X3 self-esteem. Berdasarkan persamaan tersebut, dapat disimpulkan bahwa perbandingan sosial berfungsi menurunkan self-esteem, sementara syukur berfungsi meningkatkan self-esteem pada remaja pengguna media sosial. Hasil analisis data selengkapnya dapat dilihat pada Tabel 1.

\section{Diskusi}

Berdasarkan hasil analisis data yang telah dilakukan, ditemukan bahwa perbandingan sosial yang dilakukan oleh remaja di media sosial memiliki pengaruh terhadap self-esteem yang bersangkutan $(\mathrm{p}<0,01)$. Dalam hal ini, perbandingan sosial dapat menurunkan self-esteem remaja yang melakukan perbandingan sosial, yang ditunjukkan dengan koefisien korelasi yang bernilai negatif $(r=-0,264$ dan $-0,240)$. Temuan ini sesuai dengan hasil penelitian terdahulu yang dilakukan oleh Vogel, Rose, Okdie, Eckles, dan Franz (2015) yang menemukan bahwa orang yang memiliki orientasi perbandingan sosial yang tinggi ketika menggunakan media sosial, akan berdampak pada rendahnya tingkat selfesteem yang bersangkutan. Hasil studi lain dari Vogel, et al. (2014) juga menunjukkan bahwa informasi yang mendorong seseorang untuk membandingkan diri di media sosial dapat menurunkan self-esteem-nya. Sementara Steiger, Allemand, Robins, dan Fend (2014) menemukan bahwa rendahnya tingkat self-esteem pada remaja dapat menyebabkan depresi, dan ini berhubungan dengan kompetensinya dalam hal akademik dan juga penampilan fisik. Hal ini menunjukkan bahwa kemampuan atau abilities merupakan aspek yang penting dalam menentukan bagaimana self-esteem dari seorang remaja.

Selanjutnya, hasil analisis moderated regression analysis menunjukkan bahwa pengaruh dari perbandingan sosial terhadap self-esteem tetap signifikan setelah dimoderasi oleh syukur ( $<<0,01$ ). Hasil ini menunjukkan bahwa hipotesis aktif (Ha) diterima. Peningkatan koefisien korelasi dari $-0,264$ dan $-0,240$ menjadi $-0,255$ dan $-0,198$ menunjukkan bahwa syukur berperan dalam mengurangi pengaruh negatif yang ditimbulkan oleh perbandingan sosial terhadap self-esteem pada

Tabel 1.

Hasil Uji Hipotesis

\begin{tabular}{llll}
\hline $\begin{array}{l}\text { Peran Perbandingan Sosial terhadap } \\
\text { Self-esteem }\end{array}$ & Sig. & $r$ & $\mathrm{R}^{2}$ \\
\hline Sebelum dimoderasi syukur & 0,000 & $-0,264$ dan $-0,240$ & 0,092 \\
Setelah dimoderasi syukur & 0,000 & $-0,255$ dan $-0,198$ & 0,227 \\
& & & \\
\hline
\end{tabular}


pada remaja pengguna media sosial. Hasil ini mendukung temuan penelitian Chen dan $\mathrm{Wu}$ (2014) yang menekankan bahwa individu yang memiliki gratitude atau kebersyukuran akan cenderung memiliki self-esteem yang tinggi. Pada umumnya pengaruh tersebut dimediasi oleh beberapa faktor seperti persepsi mengenai adanya dukungan sosial atau perasaan bahwa diri sendiri bernilai. Pandangan ini juga sejalan dengan hasil temuan penelitian Kong, Ding, dan Zhao (2015) bahwa kebersyukuran memiliki keterkaitan dengan self-esteem dalam meningkatkan kepuasan hidup seseorang.

Persamaan regresi yang terbentuk dari hasil penelitian ini menunjukkan bahwa perbandingan sosial dapat menurunkan self-esteem, di mana kemudian oleh syukur self-esteem tersebut ditingkatkan kembali. Peningkatan koefisien determinasi dari 9,2\% menjadi 22,7\% juga menunjukkan bahwa syukur memiliki peran yang cukup besar dalam korelasi yang terjadi. Masa remaja merupakan masa di mana individu sedang mencari identitas, sehingga seringkali remaja membandingkan diri dengan orang lain sebagai dasar dalam mengevaluasi dirinya (Baron \& Byrne, 2004; Santrock, 2003). Media sosial merupakan salah satu sumber utama perbandingan sosial tersebut, khususnya dewasa ini. Namun, mengekspos orang lain di media sosial dapat memengaruhi self-esteem remaja yang bersangkutan, terutama apabila menimbulkan rasa iri (Fardouly et al., 2015; Gonzales \& Hancock, 2011). Rasa iri menyebabkan remaja mengevaluasi negatif dirinya, merasa dirinya lebih rendah daripada orang yang menjadi bahan perbandingan sosial, sehingga menurunkan self-esteem nya (Krasnova et al., 2013). Dalam hal ini, maka adanya rasa syukur dapat mendorong remaja yang bersangkutan untuk lebih menerima kekurangan yang dia rasakan tersebut dan dapat lebih menghargai dirinya. Penerimaan ini mendorong timbulnya self-acceptance, yang dapat berpengaruh pada peningkatan kembali self-esteem-nya (Kashdan et al., 2006; Utami, 2013).

Bagaimana perbandingan sosial dapat memengaruhi self-esteem seorang remaja pengguna media sosial, baik itu meningkatkan ataupun menurunkan, akan bergantung kepada arah dari perbandingan yang dilakukan, apakah itu perbandingan sosial ke atas (upward) atau ke bawah (downward). Dalam hal untuk menimbulkan emosi positif, maka remaja akan cenderung melakukan downward comparison, yang sekaligus dapat meningkatkan self-esteem yang bersangkutan (Baron \& Byrne, 2004; Taylor, 1998; Vogel et al., 2014). Rasa kebersyukuran di sini memiliki fungsi mengarahkan seorang remaja yang mengakses media sosial untuk lebih melihat fakta bahwa masih terdapat orang-orang yang lebih tidak beruntung dibandingkan dirinya, atau dengan kata lain membandingkan diri dengan orang-orang yang dianggap berada di bawah dirinya, ketimbang membandingkan diri dengan orang yang dianggap berada di atas dirinya. Seseorang yang melakukan downward compareison atau perbandingan sosial ke bawah akan lebih mengevaluasi dirinya secara positif dan meningkatkan self-esteem-nya (Al-Banjari, 2014; Vogel et al., 2014). Dengan demikian dapat dikatakan bahwa syukur memiliki peran secara tidak langsung di dalam memediasi pengaruh dari perbandingan sosial terhadap self-esteem, yaitu dengan lebih mengarahkan remaja untuk melakukan perbandingan sosial tersebut dalam bentuk downward comparison atau perbandingan sosial ke bawah.

Penelitian ini memiliki sejumlah keterbatasan, khususnya terkait dengan alat ukur yang dipergunakan untuk perbandingan sosial. Alat ukur ini bersifat multidimensional, sehingga menjadi sulit untuk diambil kesimpulan yang bersifat tunggal atau integral ketika digunakan untuk mengukur bagaimana orientasi perbandingan sosial seseorang. Sebaiknya penelitian selanjut- 
nya menggunakan alat ukur yang bersifat unidimensional, atau akan lebih bagus apabila diperkaya dengan alat ukur yang mengukur arah dari perbandingan sosial tersebut. Keterbatasan lain adalah menyangkut pemilahan subjek yang diteliti, terutama bagaimana mengukur penggunaan media sosial beserta intensitasnya. Penelitian ke depan diharapkan dapat lebih menspesifikkan media sosial yang dipakai, misalnya hanya fokus kepada instagram atau facebook saja. Sementara pembatasan kriteria keaktifan subjek juga perlu menggunakan rumusan yang lebih terukur.

\section{Simpulan}

Terdapat peran yang sangat signifikan dari syukur dalam pengaruh perbandingan sosial terhadap self-esteem pada remaja pengguna media sosial. Syukur berfungsi untuk mengubah pengaruh perbandingan sosial terhadap selfesteem dari pengaruh negatif menjadi pengaruh positif.

\section{Saran}

Penelitian selanjutnya yang menggunakan variabel perbandingan sosial disarankan untuk menggunakan alat ukur yang bersifat unidimensional, sehingga lebih efisien daripada penelitian ini yang menggunakan skala multidimensional. Di samping itu juga dapat melibat- kan alat ukur yang berfungsi melihat arah perbandingan sosial, sehingga dapat memperkaya analisis data di dalam melihat bagaimana variabel moderator bekerja. Diharapkan juga terdapat penelitian lanjutan yang berfokus pada media sosial yang lebih spesifik seperti berfokus kepada instagram atau facebook saja. Subjek yang digunakan juga tidak hanya subjek remaja, namun juga dapat menggunakan subjek dewasa yang notabene interaksinya dengan media sosial akan memiliki pola yang berbeda dengan remaja.

Kepada lembaga pendidikan baik agama maupun umum, agar di dalam pembelajaran ilmu agama tidak hanya terfokus pada persoalan akidah, ibadah atau syariah, namun juga mampu meningkatkan penghayatan spiritual dari peserta didik, termasuk di antaranya penanaman rasa kebersyukuran. Kepada Kementerian Komunikasi dan Informasi serta lembaga terkait, diharapkan untuk dapat lebih mengontrol ataupun membatasi konten media sosial yang dapat memengaruhi self-esteem dari penggunanya, seperti misalnya body-shaming (komentar yang mencela fisik) ataupun komentar negatif menyangkut SARA dan status sosial ekonomi. Kontrol dapat dilakukan secara konstitutif dengan aturan perundangan, maupun edukatif melalui internalisasi di konten media sosial itu sendiri.]

\section{Daftar Pustaka}

Al-Banjari, R. R. (2014). Ajaibnya syukur atasi semua masalah. Yogyakarta: Sabil.

Baron, R. A., \& Byrne, D. R. (2004). Psikologi sosial. (R. Djuwita, Ed.) (10th ed.). Jakarta: Erlangga.

Baumeister, R. F., \& Finkel, E. J. (2010). Advanced social psychology: The state of the science. New York: Oxford University Press. https://doi.org/10.1093/pcp/pcs125

Chen, L. H., \& Wu, C. H. (2014). Gratitude enhances change in athletes' self-esteem: The moderating role of trust in coach. Journal of Applied Sport Psychology, 26(3), 349-362. https://doi.org/10.1080/ 10413200.2014.889255

Damian, R. I., \& Robins, R. W. (2010). Self-esteem across the lifespan: Issues and interventions. (Mary H. Guindon, Ed.). New York, NY: Routledge. https://doi.org/10.1080/08952841.2011.561147 
Emmons, R. A., \& McCullough, M. E. (2012). The psychology of gratitude. Oxford, New York: Oxford University Press. https://doi.org/10.1093/acprof:oso/9780195150100.001.0001

Fardouly, J., Diedrichs, P. C., Vartanian, L. R., \& Halliwell, E. (2015). Social comparisons on social media: The impact of Facebook on young women's body image concerns and mood. Body Image, 13, 38-45. https://doi.org/10.1016/j.bodyim.2014.12.002

Fernandez, S., \& Pritchard, M. (2012). Relationships between self-esteem, media influence and drive for thinness. Eating Behaviors, 13(4), 321-325. https://doi.org/10.1016/j.eatbeh.2012.05.004

Gonzales, A. L., \& Hancock, J. T. (2011). Mirror, mirror on my Facebook wall: Effects of exposure to Facebook on self-esteem. Cyberpsychology, Behavior, and Social Networking, 14(1-2), 79-83. https://doi.org/10.1089/cyber.2009.0411

Hadi, S. (2015). Metodologi riset. Yogyakarta: Pustaka Pelajar.

Hartono. (2013). SPSS 16.0, Analisis data statistika dan penelitian. Yogyakarta: Pustaka Pelajar.

Heatherton, T. F., \& Polivy, J. (1991). Development and validation of a scale for measuring state selfesteem. Journal of Personality and Social Psychology, 60(6), 895-910. https://doi.org/10.1037/ 0022-3514.60.6.895

Herring, S. C., \& Kapidzic, S. (2015). Teens, gender, and self-presentation in social media. International Encyclopedia of the Social \& Behavioral Sciences: Second Edition, 146-152. https://doi.org/ 10.1016/B978-0-08-097086-8.64108-9

Hidayat, M. W. (2016). 3 Media sosial favorit pengguna internet Indonesia. Retrieved from https://www.liputan6.com/tekno/read/2634027/3-media-sosial-favorit-pengguna-internetindonesia

Jalaluddin. (2009). Psikologi agama. Jakarta: RajaGrafindo.

Kashdan, T. B., Uswatte, G., \& Julian, T. (2006). Gratitude and hedonic and eudaimonic well-being in Vietnam war veterans. Behaviour Research and Therapy, 44(2), 177-199. https://doi.org/ 10.1016/j.brat.2005.01.005

Kernis, M. H. (2013). Self-esteem issues and answers: A sourcebook of current perspectives. New York, NY: Psychology Press. https://doi.org/10.4324/9780203759745

Kong, F., Ding, K., \& Zhao, J. (2015). The relationships among gratitude, self-esteem, social support and life satisfaction among undergraduate students. Journal of Happiness Studies, 16(2), 477-489. https://doi.org/10.1007/s10902-014-9519-2

Krasnova, H., Wenninger, H., Widjaja, T., \& Buxmann, P. (2013). Envy on facebook: A hidden threat to users'life satisfaction? In 11th International Conference on Wirtschaftsinformatik. Leipzig, Germany. Retrieved from https://www.semanticscholar.org/paper/Envy-on-Facebook\%3AA-Hidden-Threat-to-Users'-Life-Krasnova-

Wenninger/b775840d43f9f93b7a9031449f809c388f342291?navld=citing-papers

Lee, S. Y. (2014). How do people compare themselves with others on social network sites?: The case of Facebook. Computers in Human Behavior, 32, 253-260. https://doi.org/10.1016/ j.chb.2013.12.009

Lopez, S. J., \& Snyder, C. R. (Eds.). (2012). The Oxford handbook of positive psychology. New York, NY: Oxford University Press. https://doi.org/10.1093/oxfordhb/9780195187243.001.0001

Manfaat sikap bersyukur untuk kesehatan remaja. (2012). Retrieved from https://www.beritasatu. com/keluarga/64477-manfaat-sikap-bersyukur-untuk-kesehatan-remaja.html 
Putra, J. S. (2016). Penerimaan diri dan kebersyukuran pada mahasiswa: Studi pada mahasiswa FISIP Universitas Islam “45” Bekasi. In Prosiding Seminar Nasional Unisma Bekasi (Vol. 20 Januari, pp. 373-386).

Roesma, J., \& Mulya, N. (2018). Media sosialita, eksis narsis jadi daring darling. Jakarta: Gramedia Pustaka.

Santrock, J.W. (2003). Adolesence, perkembangan remaja. Jakarta: Erlangga.

Schneider, S. M., \& Schupp, J. (2014). Individual differences in social comparison and its consequences for life satisfaction: Introducing a short scale of the Iowa-Netherlands Comparison Orientation Measure. Social Indicators Research, 115(2), 767-789. https://doi.org/10.1007/s11205-0120227-1

Srivastava, S., McGonigal, K. M., Richards, J. M., Butler, E. A., \& Gross, J. J. (2006). Optimism in close relationships: How seeing things in a positive light makes them so. Journal of Personality and Social Psychology, 91(1), 143-153. https://doi.org/10.1037/0022-3514.91.1.143

Steiger, A. E., Allemand, M., Robins, R. W., \& Fend, H. A. (2014). Low and decreasing self-esteem during adolescence predict adult depression two decades later. Journal of Personality and Social Psychology, 106(2), 325-338. https://doi.org/10.1037/a0035133

Taylor, S. E. (1998). The social being in social psychology. In D. T. Gilbert, S. T. Fiske, \& G. Lindzey (Eds.), The handbook of social psychology. New York, NY: McGraw-Hill. https://doi.org/ 10.1111/spc3.12113

Trzesniewski, K. H., Donnellan, M. B., Moffitt, T. E., Robins, R. W., Poulton, R., \& Caspi, A. (2006). Low selfesteem during adolescence predicts poor health, criminal behavior, and limited economic prospects during adulthood. Developmental Psychology, 42(2), 381-390. https://doi.org/ 10.1037/0012-1649.42.2.381

Utami, N. M. S. N. (2013). Hubungan antara dukungan sosial keluarga dengan penerimaan diri individu yang mengalami asma. Jurnal Psikologi Udayana, 1(1), 12-21.

Vogel, E. A., Rose, J. P., Okdie, B. M., Eckles, K., \& Franz, B. (2015). Who compares and despairs? The effect of social comparison orientation on social media use and its outcomes. Personality and Individual Differences, 86, 249-256. https://doi.org/10.1016/j.paid.2015.06.026

Vogel, E. A., Rose, J. P., Roberts, L. R., \& Eckles, K. (2014). Social comparison, social media, and selfesteem. Psychology of Popular Media Culture, 3(4), 206-222. https://doi.org/10.1037/ ppm0000047

Widiartanto, Y. H. (2016). 2016, Pengguna internet di Indonesia capai 132 juta. Retrieved from https://tekno.kompas.com/read/2016/10/24/15064727/2016.pengguna.internet.di.indones ia.capai.132.juta. 
This page intentionally left blank 